\title{
INTERNATIONAL ADMINISTRATIVE LAW: A FUNCTIONAL APPROACH TO PEACE
}

\author{
HARROP A. FREEMAN*
}

I

DURING the past century, the inability of individual man in a society so complex as ours to protect himself by reliance on constitutions and private rights, coupled with the recognition of a societal interest in individual welfare, has led to deepening interest on the part of the citizen in performance of services by the government. All men have come to recognize that their "rights" are worthless except as the dayto-day operation of government realistically secures to them the wherewithal to live full, well-rounded lives. ${ }^{1}$

To meet the demands consequently put upon modern government, the administrative agency has proved peculiarly adapted, offering the advantages of expertness, specialization, combination of private and public action, continuous supervision, experimentation, preventive action and speedy, cheap and non-technical procedures. As Justice Frankfurter and others have emphasized, these agencies have superseded the legislative-judicial approach-so concerned with nebulous "rights" and aberrational controversies-with a functional approach aimed at the solution of problems. ${ }^{2}$ Whether we compare the number of administrative decisions in the United States with the number of court rulings, or consider the areas of our lives dependent on administrative regulation, it is obvious that within the nation ours is the century of administrative law.

Yet lawyers as well as laymen seem to fall into outmoded patterns of thought when they transpose their thinking into the international field. Here, they assume that charters and constitutions are sacrosanct,

* Associate Professor of Law, Cornell Law School.

1. Of what value the right to organize without the NLRB and its enforcement procedures? Or the Negro's right to "equal treatment" in the absence of effective administrative protection?

The footnotes will be largely bibliographical. For general information see FreENAN and Paullin, Road to Peace (1948); Greaves, The league Committees and Wordd Order: A Study of the Perdanent Expert Committees of the League of Nations as an Instrument of International Governaent (1931); Hill, International Administration (1931); Mitrany, A Working Peace System (1946); RanshofeNWertheimer, Victory is Nor Enough: The Strategy of Lasting Peace $306-7$ (1942); Persistent International Issues (De Huszar ed. 1947); Burns, Intermational Administration, 7 BRIT. Y. B. INT'L L. 68 (1926); Potter, Development de l'Organization Internationale 1815-1914, RECUEIL DEs CouRs 144 (1938); Reinsch, International Unions and Their Administration, 1 Ass. J. INT'L L. 581 (1907).

2. Frankfurter and Davidson, Cases on Adninistrative Law (1935); Goodnow, Comparative Administrattve Law (1893) and Principles of Administrative LaW of the United States (1905); Landis, The Administrative Process (1938). 
that the written plan of government constitutes government, that "rights" and "interests" are the chief concerns of government and legal protection-all despite the overwhelming historical evidence that a government takes on life only through cooperation and a constitution merits interest only in terms of the problems solved under it.

Recently, a number of writers have urged that we carry the national lessons to the international field and aim at international peace through functional international organization. David Mitrany, ${ }^{3}$ for example, considers the League of Nations, the United Nations Charter and proposals for world or regional federations and an "enforced" peace to be in the tradition of the Eighteenth Century and out of harmony with our times; today's "trend is to organize government along the lines of specific ends and needs . . . in lieu of the traditional organization on the basis of a set constitutional division of jurisdiction of rights and powers. . . ." Mitrany points out that while ". . . the peoples may applaud declarations of rights, they will call for the satisfaction of needs. That demand for action could be turned into an historic opportunity."

Although voiced by men of such divergent outlook as Henry Wallace, ${ }^{4}$ Wendell Willkie ${ }^{5}$ and Eric Johnston, ${ }^{6}$ the need for functional solution of the world's problems has not been universally accepted. Nicholas Spykman ${ }^{7}$ and Carl Becker, ${ }^{8}$ for example, find nationalism "the strongest political force in the modern world," a point of view which may find support in the Security Council's bickerings and the current power struggle between Russia and the United States.

Yet if a shift of emphasis from protection of private rights to a demand for public services does characterize our times, we should focus our international eye not upon the United Nations Charter's reliance on "sovereign equality," nor on a political association of "peace-loving nations," nor on plans for use of force against aggressors, but on those organizations which step by step are solving world problems-on world functional organizations. ${ }^{9}$

This article will, in consequence, first seek to indicate by example the growing powers-often infringing on "sovereignty" - which have been granted for nearly a century to international administrative organizations. By more detailed study of two representative agencies, one

3. Mitrany, op. cit. supra note 1 , at 7, 20, 21 (1946).

4. Wallace, The Century of the Coararon Mian (1943).

5. WIILKIE, ONE WORLD (1943).

6. Johnston, America's World Chance, Reader's Digest, June, 1945, p. 5.

7. Spykaran, Amerrcan Strategy in World Politics (1942).

8. Becker, How New WhI the Better WarLd Be? (1944).

9. In 1938 , almost 650 functional organizations existed, governments taling a direct part in over 130. Handeoor of Internattonal Organizations (League of Nations Publications XII) 4 (1938). By MIay, 1946, the State Department was able to list 216 international functional agencies in which the United States participated. 
taken from the League and one from the current period, attention will then be focussed on the parallelism of international and national administrative law, in the hope that the entire investigation will be provocative of that further study and interest in international administrative law which offers one of the most practical and surest avenues to world peace and order.

\section{II}

Private and public interests have always extended beyond state boundaries and created problems which demanded international solutions. International conferences of diplomats first tried to deal with these matters by treaties or conventions whose execution was left entirely to the individual states. ${ }^{10}$ Since the middle of the Nineteenth Century, however, various worldwide problems have been handled functionally through international administrative agencies.

\section{Independent Public Agencies}

The International Telecommunication Union, ${ }^{11}$ founded in 1869, has been successful in coordinating and improving international telecommunication, largely through studies and recommendations. Seventyfour states are members of the Union and 35 private companies adhere to its practices, financing the organization in proportion to their telegraphic intercourse rather than on the basis of state equality. The Universal Postal Union, ${ }^{12}$ founded in 1874, was the first international body whose permanent bureau had more than the power to gather information. It was assigned executive functions in clearing accounts, and was charged with offering opinions on disputes between members. The Union was originally "resisted in almost every country, both as an infringement of sovereignty, and as involving an abandonment of the principle by which every state, as far as it can, tries to 'make the foreigner pay' the expenses of its government." ${ }^{13}$ Now, although a

10. Hill, The Public International Conference (1929).

11. For brief treatments of the work of this Union, see Hurs, op. cit. supra note 1, at 156-7; Mance, Internattonal Teleconimunications (1943); Schmeckbier, Internationat Organtzations in Which the United States Participates 258-66 (1935); Schameckbier, International Agenctes in Which the United States Participates 264 (1946) ; Baldwin, International Congresses and Conferences, 1 AMr. J. INr'z L. 810 (1907); Lavollee, Les Unions Internationales, 1 ReviEW D'Historre Diplomatioue 347-8 (1887); Reinsch, supra note 1, at 582, 585.

12. On the Universal Postal Union see Schmecketer, Internationat OrganizaTTONs . . op. cit. supra note 11, at 31-43; HILE, op. cit. supra note 1, at 13, 157; BEALEs, The History of Peace: A Short Account of the Organized Movements for International Peace 158 (1931); Brierly, The Law of Nattons 200-1 (1928); Vinacke, International Organizations 407-8 (1934); Ley, The Genesis of the Univerisal Postal Union (1927); SchareckbIer, International Agencies . . op. cit. supra note 11 , at 297; Baldwin, supra note 11 , at 809,811 .

13. See BRIERLY, op. cit. supra note 12, at 201. 
state is free to refuse to ratify changes in Union procedure, sovereignty can only be so preserved by withdrawal from the Union-a price no state, no matter how determinedly sovereign, can afford to pay. ${ }^{14}$

In the field of transportation, the International Union of Railway Freight Transportation has served as a clearing house for information, has facilitated financial relations and has aided the arbitration of controversies. ${ }^{15}$ Its expenses are borne by the member states in proportion to the length of their railroads. International control of waterways has existed since 1804. The Rhine Commission is an inspecting, ruleenforcing, fee-collecting body, while the two Danubian commissions have policed the river, improved navigability, established and enforced navigation rules, and taxed shipping. ${ }^{16}$

Successful attempts have been made internationally to deal with the production and distribution of various commodities. ${ }^{17}$ The 1937 agreement adopted by the International Sugar Commission represented a considerable modification of the principle of absolute state sovereignty as to international trade in that the representation of a state was determined exclusively by the extent of its dealings in sugar. ${ }^{18}$

Certain other international groups, although limited to informational functions, have sponsored uniformity through independent national action. ${ }^{19}$ It is perhaps significant now, when national sovereignty has

14. The Union continued to function despite World War II; neither Italy nor Japan resigned and the Union even operated in territories like Ifanchuria which were not subject to its regulations. See NIEMrEYeR, LAW WITHOUT ForCE 236 (1941).

15. Cematiberiain, International Organization 501-2 (1942); Baldwin, saspro note 11 , at 812, 814; Reinsch, supra note 1, at 589-93.

16. On the regulation of the Danube see Hrr., op. cit. sipra note 1, at 22-3, 35-8; Baldwin, sutpra note 11, at 810, 812; Reinsch, stipra note 1, at 619; Sherman, International Organization of the Danube, 17 Axr. J. INT'L L. 438 (1923).

On the international control of other waterways, see $\mathrm{Hnz}$, op. cif. sispra note 1 , at

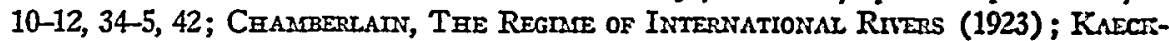

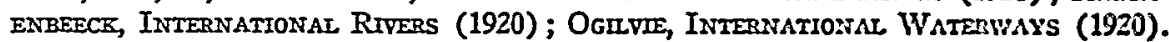
See also 112 British \& Foreign State Papers 176-7 (1919); 10 Noutenu Recueal GENERALE (2d series) 414 (1852).

For a discussion of the UN's European Central Transportation Organization, which is planned to take over control of most European rivers, see Wehle, Intcriational Administration of European Inland Waterz'ays, 40 Axr. J. INT'L. L. 100 (1946).

17. On the first sugar agreement, see Chaxmerlain, op. cit. supra note 15, at 492; Fry, Bricks Without Mlortar: The Story of International Cooperatioiz 42 (1938); Baldwin, supra note 11, at 816; Reinsch, supra note 1, at 602 .

18. Cenamererlain, op. cit. supra note 15, at 492, 509.

19. On the Union for the Protection of Industrial Property (patents and trademarls), see Brierly, Laiv of Nations 201 (1928); Ladas, The Intersiationial Protrctio:i of Industrial Property (1930); Schumeckbier, Internationial Organtzations . . op. cit. supra note 11, at 66-71; Baldwin, supra note 11, at 813 ; Lavollec, supra note 11, at 359; Reinsch, supra note 1 , at 597 .

On the International Bureau of Weights and Measures, see Scrasecrsones, InitzonaTiONAL ORGaNizations . . o op. cit. supra note 11, at 44-50, 113-18. 
rendered a world legislature unlikely, to recall that almost yearly since 1892 delegates from national parliaments have been meeting in an Interparliamentary Union where international issues are discussed so that the national delegates may reflect these discussions in national laws. ${ }^{20}$ Nicholas Murray Butler once remarked that in this Union "lies the germ of a coming federation of the world's legislatures." 21

\section{Private Agencies}

Great as has been the growth of public international functional organization (the above has hardly begun to indicate the number or importance of such bodies ${ }^{22}$ ) it has by no means entered all of the fields in which international interests exist. Private international organizations have also played a significant role, particularly in leading to the establishment of official counterparts. Clyde Eagleton, indeed, goes so far as to say that "in most [public international] unions, the initia. tive came from private enterprise." ${ }^{23}$ Among such organizations have

On the International Bureau of Commercial Statistics, see id. at 314-18; Katufmann, Les Unions Internationales de Nature Economique, 3 REcueIL DES Couns 233 (1924).

On the International Institute of Agriculture-from which it was once estimated the United States Department of Agriculture received 30\% of its information, sec Houson, The International Institute of Agriculture: An Historical and Critical Analxsis of Its Organlzation, Activities, and Policies of Adurinistration (1931) SchMecrbier, International Organizations . . op. cit. supra note 11, at 174-83; Kaufmann, stpra, at 190; Reinsch, supra note 1, at 604-7.

20. Beales, History of Peace 191-5, 225 (1931) ; Schmeckbier, International Organizations ... op. cit. supra note 11 , at $233-9$; HaNdBook of IN'TERNatronal ONGANIZATIONS 16-7 (1938).

21. Butler, The International Mind 39 (1912).

22. The following is a statístical summary of the organizations listed in the HANDBOoK of International Organizations. Classified as semi-public are all the organizations in which governments participated, financially or otherwise.

I. Pacifism Field

II. Religion, Humanitarian

III. Arts and Sciences

IV. Education

V. Students and University

VI. Medicine and Hygiene

VII. Law and Administration

VIII. Press

IX. Feminism

$\mathrm{X}$. Labor and Professions

XI. Agriculture

XII. Econ. and Finance

XIII. Trade and Industry

XIV. Communic. and Transit.

XV. Sport and Tourism

XVI. Miscellaneous

Public
1
4
14
6
0
7
10
0
1
0
2
2
14
17
1
0
$\frac{79}{79}$

Semi-Public

$\begin{array}{r}2 \\ 3 \\ 19 \\ 2 \\ 0 \\ 4 \\ 8 \\ 0 \\ 0 \\ 0 \\ 5 \\ 1 \\ 2 \\ 5 \\ 0 \\ 1 \\ \hline 55\end{array}$

23. Eagleton, International Governaent 238 (1932). Cf. Manier, Foundations of Modern World Society 525 (1941). 
been the International Red Cross, the International Health Division of the Rockefeller Foundation, the International Migration Service, and the International Association for the Testing of Materials. ${ }^{24}$ Linden A. Mander lists 422 scientific subjects dealt with by private international conferences between 1930 and 1939. ${ }^{25}$

\section{Inter-American Agencies}

Today's flourishing inter-American agencies are a far cry from the first tentative gathering of April, 1810.25 Progressively, the PanAmerican Union has been assigned more important duties; within its framework has been created a multitude of agencies to deal with all types of hemisphere problems.

Perhaps among the most important and typical in scope of operation is the Inter-American Development Commission, formed in 1940 to concern itself with the development of the economic resources of the hemisphere. The Commission operates in each country through a National Development Commission. Its activities to date have included the dissemination of information concerning industrial processes and the establishment of model plants, the opening of markets in the United States for the handicraft products of Latin America, and the development of plans for large capital investment in industrial projects. Under its auspices, a Conference of Commissions of Inter-American Development was held in New York in 1944. This Conference adopted extensive recommendations concerning policy on technical standards, agriculture, power, investments and credit, currency stabilization, taxation, customs unions, transportation and a number of other subjects, and has had a powerful effect upon governmental policy and the course of inter-American economic relations. ${ }^{27}$

The special Inter-American Conference on Problems of War and

24. See GREAVES, op. cit. supra note 1. As might be expected, some agencies cscupy a middle ground, quasi-private being a suitable classification. Typieal was the International Broadcasting Union which, for a number of years, regulated European radio to a certain extent. See ChassperdaIN, op. cit. sitpra note 15, at 503-4; Whitton, Radio oficr the War, 22 ForkigN AFFaIRs 313 (1944).

25. MAANDER, op. cit. supra note 23 , at 535-40.

26. General books on the Inter-American System include: BuL, TuE Prodress of Intre-Axierican Organization (1944); Green, Pan Astericisi Progress (1942); Huniphrey, The Inter-Aarerican Systear: A Canadian Viev (1942); Prewetr, The AMIERICAs and Todrorrow (1944); Inter-Aarerican Solidarity (Laves ed. 1941). For

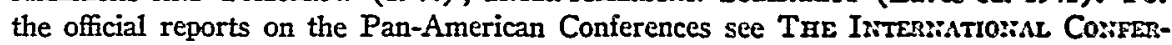

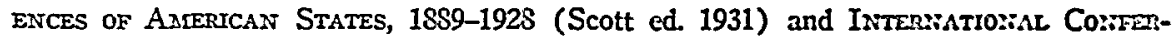
ences of Adrerican States, 1933-1940 (Scott ed. 1940). See also Hin, Tne Puruic Ir:terrational Conference (1929); Schareckbier, INternational Orgasizations . . . op. cit. supra note 11, at 75-105; KeICHNER, INTER-AxirRICAN Confrerexcess 1826-1933 (Dep't of State, 1933).

27. Green, Pan-American Progress 99-101 (1942); Proceenrigas of tare Co:iFERENCe of Coarartssions of INTER-AAIERICAN Developarent (1944). 
Peace in 1945 went so far as to empower the governing board to take action "on every matter which affects the effectual functioning of the Inter-American System and the solidarity and well-being of the American Republics." 28

\section{The League's Legacy}

Although the effective work in international administration done by the League of Nations has been largely obscured in the histories by attention to the political and "collective security" aspects of the League, such administrative experience forms the real basis for presentday world cooperative effort. ${ }^{29}$ Such success as the League had was largely due to its administrative agencies, handling refugee control and financial reconstruction in Greece, Bulgaria and Danzig, ${ }^{30}$ to the Communications and Transit organization, ${ }^{31}$ the Health organization, ${ }^{32}$ the Permanent Central Opium Control Board, and the ILO and to the League Secretariat, a true international civil service. ${ }^{33}$ To a remarkable degree, the Secretariat solved the problems inherent in a service where politics intersects administration: e.g., national representation on the staff and in high positions, ${ }^{34}$ relations with governments and language difficulties.

As the Supervisory Commission, which handled the wartime administration of the League's activities, stated in 1943, the League's organs constituted "the one great storehouse of experience in international cooperation and administration." ${ }^{35}$ From it have come many United Nations plans and many of the trained international civil servants now working in United Nations agencies.

28. 12 Dep'T StaTe BULI. 341 (1945).

29. See, e.g., on the economic work of the League, Heilperin, Economic and Financial Issues in Wortd Organization 50-82 (1942); TEN YeArs of World CoOperution 178-206 (League of Nations, 1930) ; KNudSEN, A History of THE LEAGUE of NATrong 206-24 (1938); see also Report on the Work of the League Durnag the War 85 (League of Nations, 1945).

30. HiIl, International Administration 84-9 (1931).

31. See Greaves, op. cit. supra note 1, at 143-55; Hostie, Communications and Transit in WorLd Organization 158 (1942).

32. GREAVEs, op. cit. supra note 1, at 85; MANDER, op. cit. supra note 23, at 10-25; SchateckBIER, International Organizations . . op. cit. stipra note 11, at 204-15; Boudreau, International Health Work, and Health, Nutrition and Housing in WORLD ORganization 83 (1942); Pioneers in World Order: AN American Appraisal of tue LEague of Nations 193-207 (Davis ed. 1944).

33. HIIL, International Adainistration 101 (1931); Morley, Tue Society of Nations; Its Organization and Constitutional Devejopment 250 (1932); Boudreau, International Civil Service: the Secretariat of the League of Nations in DAvis, op. cit. supra note 32 , at 77.

34. Nations do not seem to require representation where the agency has no political function, e.g., the Universal Postal Union with an all-Swiss personnel.

35. REPORT ON THE WORK OF THE LEAGUE 1942-1943 1 (League of Nations, 1943). Quoted by Boudreau in DavIs, op. cit. supra note 32, at 84-5. 


\section{The United Nations}

With the average American, who has lived under legislative, executive and judicial departments coordinated by a constitution unchanged over 175 years, the foregoing sketchy survey of functional organizations is likely to leave a sense of disunity-many little groups, each worthy but unrelated to each other. Perhaps in the integrated agencies being developed by the United Nations may be found the answer to this objection.

In the establishment of the Economic and Social Council (ECSOC) as one of the three councils of the United Nations is found a recognition that peace depends more on solution of problems in the area of social structure and economics, whereby men live, than on solution of political disputes between nations to which men swear allegiance. ${ }^{\text {is }}$

Indicative of ECSOC's scope are the commissions already set up by it: fiscal, population, transport and communication, economic and employment, narcotic drugs, social, status of women, human rights (with sub-commissions on minorities, discrimination, and freedom of information and press), and statistical. The World Health Organization (WHO), established in 1946, is the first functional organization to arise from a conference called by ECSOC.37 Members of the UN, neutral and enemy nations, and dependent territories are included. Sanitary and quarantine measures can be adopted by a simple majority vote and have immediate effect, except as to those members who, within a stated period, notify the Director of their rejection or reservation. WHO is the first permanent specialized agency to include the Soviet Union ${ }^{38}$ but, perhaps on that account, at this writing the United States has not yet joined. ${ }^{39}$ A number of other specialized agencies are planned or existing under the aegis of ECSOC, among them the United Nations Educational, Scientific and Cultural Organization (UNESCO) ${ }^{40}$ and the International Trade Organization (ITO).

36. The Social and Economic Council is given the task of promoting, under authority of the General Assembly:

"a. higher standards of living, full employment, and conditions of economic and social progress and development;

b. solutions of international economic, social, health, and related problems; and international cultural and educational cooperation; and

c. universal respect for, and observance of, human rights and fundamental freedoms for all without distinction as to race, sex, language, or religions." (U. N. CaAsTER Art 55).

37. See Stampar, A New World Healtis Organization, 12 Fres Worso 11-13, 15 (1946); 16 Dep't State BuLI 26 (1947).

38. Sand, The World Health Organization, 35 Sunvey GrapHic 352-3 (1946).

39. See Time, April 5, 1948, p. 49.

40. See Leland, The Background and Antecedents of UNESCO, Arrenrcari Pamosophical Soctety Proceednas 299 (1946); 13 Dep't State Buli 373 (1945); Tre Defense of Peace: Docuarents Relating to UNESCO (Dep't of State, 1946); 
ECSOC has granted status as consultants to such divergent-even conflicting-groups as the World Federation of Trade Unions, the American Federation of Labor, the International Cooperative Alliance and the International Chamber of Commerce. ${ }^{41}$ The Council is, moreover, the chief coordinator between existing international functional agencies and the main United Nations organization. In performing this task, ECSOC has established relations with the International Labor Organization, the Food and Agricultural Organization, the International Bank for Reconstruction, the International Monetary Fund and the International Civil Aviation Organization, and plans ties with the International Postal Union, the International Telegraphic Union and others already mentioned. ${ }^{42}$

A number of other organizations, formed within the past few years, fall loosely within the United Nations orbit. UNRRA, organized in 1943, represented a new pattern in international functional organization. Previous' agencies, like the International Labor Organization ${ }^{43}$ and the Postal Union, had been representative bodies functioning in limited spheres, largely by recommending action to member governments. UNRRA was an operating agency handling a multitude of diverse problems as they arose; it needed and was granted unprecedented powers to act without reference back to the member states. It functioned jointly with governments and private agencies. Russia cooperated fully in this organization and was, indeed, the spokesman for those who did not want to see it end in 1946.

The constitution of the Food and Agricultural Organization (FAO) illustrates some additional new approaches to international organization. To insure permanence, it prevents withdrawal during the first four years of membership and conditions later withdrawal on one year's notice. Amendments to the organization's charter, with some exceptions, may be adopted by a two-thirds vote. The extent of possi-

SCHMeChbier, Internattonad Agencies . . o op. cit. supra note 11, at 135-9; De Huszar, Peace Through Education, 11 FREE WORLD 25 (1946).

41. The Economic and Social Conncil, 2 UN WeEkLY BULL. 157 (1947).

42. 2 UN WEERLY BULL. 83, 133 (1947).

43. Too familiar to be treated at length here, the ILO has often been praised as tho international functional organization par excellence. Its continuous operation throughout the war, its pattern of representation by government, labor and industry and the adherence of sixty nations partially justify the reputation.

One of the best earlier treatments of the agency is The International Labor Organization, 166 Annals (1933) (a survey by 21 experts). See also Hirl, International Administration 112-16, 208, 211-13 (1931); SchmeCKBiER, International Agencies in Which the United States Participates 215-24 (1946). In addition to specialized studies, note the following periodic publications: Official Bulletin; Legislative Serues; International Labor Review; Industrial Safety Survey; I.L.O. Yeakbook; Yearbook of Lajour Statistics; The I.L.O. At WorK; The International Labour Code, 1939. 
ble FAO functions may be seen in Sir John Orr's report of July, 1916, proposing a buffer food supply scheme whereby the FAO would buy stocks of food in falling markets, and sell on rises, the objective being always to keep a substantial reserve stock available for emergencies. This was amplified by the FAO Standing Committee on Economics and Marketing to include a two-price system under which countries inhabited by persons eating less than an agreed minimum would buy at a lower price. ${ }^{44}$

The International Monetary Fund was designed to overcome the impediment presented when a nation's imports temporarily exceed its exports. Each member contributes to the Fund an initial sum determined by various indices of ability to pay. ${ }^{45}$ When a nation experiences balance-of-payment difficulties, it can exchange its currency up to a fixed quota for that of its creditor and redeem its own when its position improves. The Fund is also intended to stimulate international financial transactions by maintaining monetary parity. The Fund does not claim to have an answer to two pressing international monetary problems - scientific determination of monetary parities, and flight of capital, often referred to as "hot money"-but it does establish an agency to experiment with both problems. In structure the Fund is more like a public corporation than an international bureau. It is controlled by a board of governors on the basis of majority vote and is operated by a managing director and a staff which he employs. ${ }^{45}$

The International Bank for Reconstruction and Economic Development is a credit-facilitating, credit-securing agency, guaranteeing private loans, or, where this cannot be arranged, lending its capital. The Bank is directed by a board of governors; its original capital comes from initial contributions of members based on volume of trade and income; and it is intended to be self-supporting from interest and commissions on loans it negotiates and return on reserve investments. ${ }^{47}$

\section{Summary}

As a result of this cursory survey, can we summarize some aspects of international functional organization before passing on to international testing of some of our national administrative law rules?

44. N. Y. Times, Jan. 25, 1947, pp. 1, 5. Also proposed are a number of commodity agreements. For background material, see: sugar, 16 DEP'T STATE BuLs. 43 (1947); wheat, id. at 61 ; cotton, 15 Dep't State BuLr. 1075 (1946); wool, id. at 1163; tin, id. at 663 ; rubber, $i d$. at 1054 .

45. E.g., $2 \%$ of its 1939 income, $5 \%$ of its gold convertible exchanges as of Jan. 1, 1944, 1\% of its annual imports for 1934-3S. Sumberg, Financing Intcrnational Institstions, 13 Soctal Research 2S9-90 (1946).

46. Id. at 284-99; United Nations Mfonetary and Finatictal Confenen:ee, Bretton Woons (Dep't of State, 1944); Schareckbier, Internatronal Age:scies . . o op. cit. supra note 11 , at $65-70$.

47. See authorities cited note 46 supra, and for a thorough treatment of the predecessor International Bank see Heyarann, Plan for Perarastent Peace (1941). 
The actual machinery exists for solving almost any international problem we desire solved. Trained personnel and tested techniques are available. Moreover, there is far greater willingness to use and greater success in use of this machinery than is generally recognized. Much is and can be accomplished by indirection which could not be achieved head-on. International functional agencies have made severe inroads on the concept of absolute national sovereignty.

All international cooperation is built on the shoulders of the past. Nearly every agency functioning today has had its antecedents. The FAO would have been impossible but for the International Institute of Agriculture of 1905, the League Committee on Nutrition, the Wheat Agreements of 1942, UNRRA and the Joint Food Board. The plan for ECSOC was the very one which the League was in the process of adopting in 1938 after the Bruce Report. ${ }^{48}$ An architect's drawing of a house may be a beautiful thing, but it is the beam-by-beam building of the carpenter which makes the structure a reality. The experience to date with international administrative agencies indicates that through their gradual expansion the palace of peace may come to be built.

III

The concern of the lawyer is, naturally, primarily with the manner in which his professional skills may be employed to reach the desired goal of international peace and order. In the past he tended to doubt that International Law was "law" because it related only to nations and nations were not his clients; he observed no international "courts" or agencies before which to practice; he found little similarity between international questions and procedures and those he was familiar with in daily practice. Now it appears that functioning international agencies have created techniques and methods for solving international problems and developed concepts of law similar to those familiar to local lawyers. To make clear the essential familiarity of international administrative law, it would seem desirable to examine several typical operating agencies.

\section{The International Trade Organization}

The International Trade Organization (ITO), recently formed under ECSOC, seeks to set up a code of principles to be followed by the nations in shaping their international commercial policies: general equality in the treatment of all nations; elimination of exchange restrictions, quotas and embargoes except for certain purposes; elimina-

48. REPORT ON THE WORK OF THE LEAGUE DURING tre WAR 20 (League of Nations, 1945). The report of the Bruce Committee was published as a Special Supplement to 19 Monthly SuMMary of the League of Nations (Aug., 1939). 
tion of export subsidies; reciprocity in trade agreements, with certain safety valves; and prohibition of price fixing, export limitation and suppression of technological advances. ${ }^{49}$ The organizational machinery includes the usual Conference, Executive Board, Secretariat and Commissions.

The fundamental procedural framework of the ITO bears marked resemblance to administrative law patterns long in use in this country: a member (nation) files a proposal; "the Organization shall then promptly examine the proposed measure to determine whether it concurs in it"; if it concurs and other members may be affected, "the Organization shall sponsor and assist in negotiations" and the members shall, "unless the Organization decides otherwise, proceed continuously with such negotiations with a view to reaching substantial agreement," the organization being authorized to "release the applicant member from any obligation." 50 This last so-called dispensing power is granted in varying forms in other parts of the charter. ${ }^{51}$ Numerous provisions give the agency power to render decisions, either semi-legislative ${ }^{52}$ or semi-judicial ${ }^{53}$ in nature.

Although no international "police force" exists to "enforce" the decisions, effective ways of carrying them out are provided. Members may withdraw or they may be released from their obligations to the violator.

49. Draft Charter for the International Trade Orgasization of the Uzitred Nations Art. 1:

1. "To assure a large and steadily growing volume of real income and effective demand, to increase the production, consumption and exchange of goods and thus to contribute to a balanced and expanding world economy.

2. "To foster and assist industrial and general economic development, particularly of those countries which are still in the early stages of industrial development, and to encourage the international flow of capital for productive investment.

3. "To further the enjoyment by all countries on equal terms, of access to the markets, products and productive facilities, which are needed for their economic prosperity and development.

4. "To reduce tariffs and other barriers to trade and to eliminate discriminatory treatment in international commerce.

5. "To enable countries, by increasing the opportunities for their trade and economic development on a mutually advantageous basis, to abstain from measures which would disrupt world commerce, reduce productive employment or retard economic progress.

6. "To facilitate through the promotion of mutual understanding, consultation and co-operation the solution of problems relating to international trade in the frelds of employment, economic development, commercial policy, business practices and commodity policy."

50. Art 13, I2(a) and (c); $\{3$ (a), (b), (c). A similar obligation of negotiation as to reduction of tariffs is found in Art. 17, $\llbracket 1$; see also Art. 65, $\llbracket 2$.

51. See also Art. 23, โ3(a); Art. 27, โ3; Art. 43, โ2.

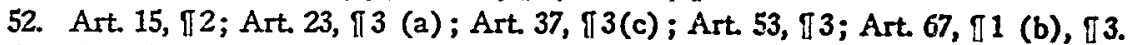

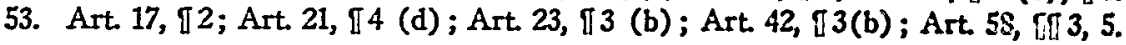


Self-help is sanctioned, and remedial action against a violator may be requested and taken even by unharmed members in accordance with their own laws. ${ }^{54}$

Among the chief functions of the ITO are to aid in consultations, ${ }^{56}$ to require and receive reports and information, ${ }^{56}$ and to make studies and recommendations ${ }^{57}$ - which are generally to be given effect.

Rule making and administrative discretion are two administrative powers most frequently granted on the national level for they reveal administrative law in its most effective light-keying general policies and rules to specific and changing facts and problems. These play an important part in the ITO. ${ }^{58}$ Another power, that of cooperating with and utilizing the services of other agencies, ${ }^{59}$ is carried to an extreme in provisions ${ }^{60}$ establishing a coordinated policy with the International Monetary Fund whereby the findings of fact and determinations of the Fund are binding on the ITO. Apparently subdelegation of powers is contemplated by the provisions for separate Commodity Control Councils, with their own rules of procedure, ${ }^{61}$ and for creation of such commissions as the Organization may require. ${ }^{62} \mathrm{~A}$ "necessary and proper" clause further expands the breadth of ITO powers. ${ }^{63}$

Many will still look to the procedural controls over the agency and the extent of judicial review before concluding that they have seen international administrative law, but a glance at the procedural pattern embodied in the chapter on "Restrictive Business Practices," modeled after our own anti-trust laws, may suffice to set all minds at rest. ${ }^{64}$ Other procedural provisions for investigation, decision, arbi$\pi 1$.

54. See Art. 17, $\llbracket 2$; Art. $21, \llbracket 4$ (d) ; Art. 13, $\llbracket 4$ (c) ; Art. 45, $\llbracket \llbracket 8,9,11$; Art. 47,

55. Art. 21, $\Uparrow 4(\mathrm{a})$; Art. 40, $\Uparrow 2$. Art. 41 defines the duty of consultations: "Each Member shall accord sympathetic consideration to, and shall afford adequate opportunity for consultation regarding, such representations as may be made by any other Member. ..." See also Art. 45, $\llbracket 1$; Art. 47, $\pi 6$; Art. $42, \llbracket 3$ (a).

56. Art. 24, $\llbracket 8$; Art. 25; Art. 31, $\llbracket 3$; Art. 34, $\llbracket 2$; Art. 35, $\llbracket 2$; Art. 37, $\| 11,3$ (c) ;

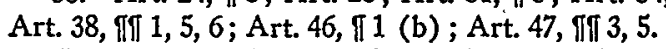

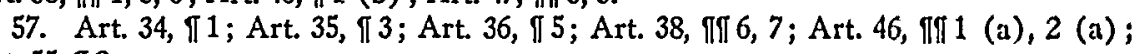
Art. 55, $\pi 2$.

58. On discretion: By such words as "... shall provide to the satisfaction of the Organization," Art. 24, ๆf 7(a), 8; see also Art. 14. On rule making: ". . . shall formulate rules governing the conversion by Members of any foreign currency," Art. 34, $\{5$ (c); “. . shall adopt its own rule of procedure," Art. 77, $\pi 1$; see also Art. 44, $\pi 3$ (g); Art. $75, \pi 2$.

59. See Art. $69, \pi(e)$; Art. 84.

60. See Art. 24.

61. See Art. 61.

62. Art. 79.

63. Art. 69 (d) : ". . . and to take any other action necessary and proper to carry out the provisions of this Charter. ..."

64. See Art. 44 et seq. 
tration and administrative appeal carry out the same administrative pattern..$^{65}$

It is the giving of legal personality to the ITO ${ }^{\circ}$ and authorization of true legal review by the International Court of Justice that form the keystones of this procedural structure. Appeal of the Executive Board's decisions to the Conference is provided ${ }^{67}$ - and the member must exhaust the administrative remedies before resorting to others. ${ }^{\mathrm{C}}$ Advisory opinions from the International Court of Justice are authorized on any legal question and certain resolutions and all decisions are "subject to review" by the Court. "The opinion of the International Court of Justice upon the questions referred to it shall be binding upon the Organization." ${ }^{69}$ Pending appeal the administrative decision stands. Here is the adoption into statutory form of the rules of administrative law which have been worked out through case law nationally.

\section{International Control of Drugs}

International control of drugs has developed over a number of decades into perhaps the most effective administrative system yet established. No more conclusive proof could be offered than the fact that the control structure continued to operate during the last war with remarkable success. ${ }^{70}$ It is extremely complex, regulating drugs from the raw product, through the exporting country, to the importing company, through the manufacturer, wholesaler and retailer to the ultimate consumer. A brief summary of the central technique may be of value. Countries furnish estimates of their needs. Producing countries are not allowed to produce more than enough for their needs plus authorized exports. Only an authorized exporter having an export certificate may export and only after receiving an import certificate issued by the importing government. The importing government is notified of shipment, the exporting government is notified of arrival, and both countries notify the Permanent Central Board. The licensed importer delivers the material to a licensed manufacturer who must keep accounts of amounts received, their use, and disposal and must make reports to a national narcotics commissioner. A manufacturer may sell only to a licensed wholesaler, a wholesaler only to a licensed retailer and a retailer only to a consumer possessing a physician's prescription. Books must be kept and inspected all along the way. A limited amount of

65. See Art. 90.

66. Art. 86.

67. Art. 90, โ1 3 .

68. Art. $92, \llbracket 3$.

69. Art. 91 .

70. The most authoritative treatment is Reneosg, Internationar Drug Costrod (1947). There are six conventions, the first four dealing with Drug Control generally and 
government stock-piling is permitted. ${ }^{71}$ National and international administration are here interrelated parts of one structure.

A part of the rule making power frequently used in national administrative law is the prescription of forms, issuance of instructions and interpretations of the basic statute. These are all regularly employed in international drug control. Here we find the first and only complete commentary on a League convention by the Secretariat. ${ }^{72}$ In 1937 the Supervisory Body issued a "guide" for use by government authorities in applying the estimate system, ${ }^{73}$ and in 1939, to aid in detecting commercially-named drugs containing narcotics, an exhaustive list was drawn up. ${ }^{74} A$ list of articles exempted under Article 8 of the 1925 convention, ${ }^{75}$ a list of authorized factories ${ }^{76}$ and current lists of the local authorities authorized to issue certificates of export and import 77 have also been furnished. The Advisory Committee and Permanent Central

the last two with opium smoking (each will be referred to in this article by its ycar of adoption) :

The International Opium Convention concluded at The Hague on Jan. 23, 1912. 8 TREATY SerIes 189 (League of Nations, 1922).

The International Opium Convention signed at Geneva on Feb. 19, 1925. 81 TREsTX SERIES 317 (League of Nations, 1928-9).

The Convention for Limiting the Manufacture and Regulating the Distribution of Narcotic Drugs, signed at Geneva on July 13, 1931. 139 TrEAty SERIEs 301 (League of Nations, 1933-4).

Convention of 1936 for the Suppression of the Illicit Traffic in Dangerous Drugs, signed at Geneva on June 26, 1936. 198 TrEaty Series 299 (League of Nations, 1939).

Agreement concerning the Suppression of the Manufacture of, Internal Trade in, and Use of, Prepared Opium, signed at Geneva on Feb. 11, 1925. 51 Tresty SERIEs 337 (League of Nations, 1926-7).

Agreement concerning the Suppression of Opium-Smoking, signed at Bangkok on Nov. 27, 1931. 177 Treaty Series 373 (League of Nations, 1937).

71. See Renborg, op. cit. supra note 70 , at $7-13,22$, for a particularly simplified explanation.

72. Convention for Limiting the Manufacture and Regulating the Distribution of Narcotic Drugs of July 13, 1931: Historical and Technical Study, L. N. Doc. C. 191. M. 136. 1937. XI (1937).

73. Estimated World Requirements of Dangerous Drugs in 1937, L. N. Doc. C. 547. M. 353. 1937. XI (1937).

74. Revised List Drawn Up by the Sub-committee of Experts of Drugs, Preparntions and Proprietary Medicines Coming Under the Hague (1912) and Geneva (1925) Opium Conventions and the Limitation Convention (Geneva, 1931). L. N. Doc. C. 348. M. 263. 1939. XI (1939).

75. Recapitulatory List of Preparations Exempted from the Provisions of the 1925 International Opium Convention by Application of Article 8 of that Convention. L.N. Doc. C. 114. M. 54. 1932. III (1932).

76. L. N. Doc. C. L. 84. 1940. XI, Annex (O.C. 1793) (1940).

77. Studies \& Documents Regarding the Working of the System of Import Certificates and Export Authorizations. L. N. Doc. C. 268. M. 185. 1939. XI-O.C. 1535 (m) (corrected 1941, 1942, 1945, 1946). 
Opium Board have established standard forms. ${ }^{78}$ Moreover, while most of the actual statutory implementation of drug control is by national legislatures, the central bodies have drawn up and circulated minimum rules for the control of pharmacies and a Model Administrative Code. ${ }^{79}$

The agency also possesses dispensing powers to exempt certain preparations of drugs. ${ }^{80}$ It conducts studies and makes recommendations. ${ }^{81}$ Article 10 of the 1925 Convention authorized recommendations that the convention be extended to drugs not covered. Article 11 of the 1931 Convention went farther in authorizing a special committee to rule mandatorily on whether specific drugs should be covered. The central board employs the usual method of publicity to gain uniformity of practice which it cannot compel..$^{82}$ This should not imply that there are no enforcement powers. An embargo may be recommended; ${ }^{83}$ the nations are required to impose adequate penalties; ${ }^{84}$ extradition is

78. For typical forms, see: Annual Governmental Report: Form of Annual Reports, L. N. Doc O.C. 1600. Model form of import certificate: RessosG, op. cit. supra note 70, at 249. Annual estimates: id. at 259. This form contains several pages of tables of equivalents and instructions.

79. Traffic in Opium and other Dangerous Drugs: Mrodel Administrative Codes to the International Opium Conventions of 1925 and 1931. L. N. Doc. C. 774.25.365.1932. XI. It can be seen that this is largely interpretive of the convention from the following passage from the code:

"The term 'reserve stocks' should be taken to mean the nornal working stocks maintained by manufacturers and wholesalers for the normal domestic consumption of the country, for conversion in the country, and for export. The effect of this interpretation will be that, in making estimates and in compiling statistics of reserve stocks, Governments will not take into account stocks in the hands of retailers."

SO. Art. $\mathrm{S}$ of 1925 Convention.

81. In addition to those referred to elsewhere see: studies on the operation of the system and suggested improrements, Studies and Documents Regarding the Worling of the System of Import Certificates and Export Authorizations, L. N. Doc. C. 434. M. 225. 1935. XI; C. 26S.1I.185.1939.XI; and Opium Advisory Committee Series O.C.1535; against the desirability of granting general licenses, Report to the Council on the Worl: of the 20th Session, L.N.Doc. C.253.M1.125.1935.XI.p. 13; on the means of stopping illicit traffic, RENBORG, op. cit. supra note 70, at 142-3; and on the cure of drug addiction, L.N.Health Comm. Doc. C.H. 1075, C.H. 1085 series. Its recommendations are often almost decisions-see, as to whether synthetics are covered by the convention, Report to the Council on the Work of the 17th Session, L.N.Doc. C.642.M1.305.1933.XI, p. 4.

82. On cases of illicit traffic, see ReNEORG, op. cit. supra note 70, at 143. For all Opium Advisory Committee documents, see id. at 1S9. Even on "estimates," where the country's statement is final, the Supervisory Body may censure a government by accompanying the estimate with a comment.

83. Art. 24 of 1925 Convention; Rentorg, op. cit. supra note 70, at 41-2, 195, 201-3.

84. See Art. 28 of 1925 Convention: "Each of the Contracting Parties agrees that breaches of its laws or regulations by which the provisions of the present Convention are enforced shall be punishable by adequate penalties, including in appropriate cases the confiscation of the substances concerned." 
authorized and is not limited to the usual "serious crimes"; 85 the Advisory Committee may censure a government; ${ }^{86}$ a party may be treated as breaching the convention; ${ }^{87}$ government inspectors may be stationed day-by-day in factories; ${ }^{83}$ and a special police force is contemplated..$^{89}$

The importance of the drug control agencies ought not to be underestimated. The system is universal even as to non-members since estimates are made for them; ${ }^{90}$ its success may be measured by the fact that it cut illicit traffic $75 \%$ in morphine, $98 \%$ in diacetylmorphine and $75 \%$ in cocaine from 1928 to 1938 . Its usefulness as a pattern, should we ever attempt a control of the traffic in arms, is marked and has already been studied. ${ }^{91}$

\section{IV}

This article has been severely cut to make it suitable for general publication. It is not exhaustive even of the few fields covered. Other writers have compiled material as to other specific agencies, ${ }^{92}$ but additional studies are needed. Most authors, like this writer, have sought to be provocative of study in the whole field of international administrative law, because they see in this law one of the surest avenues to peace and order. ${ }^{93}$ It must not be forgotten that there is a quantity of law on such administrative law questions as the personality

85. Arts. 7, 8, 9 of 1936 Convention ; RENBORG, op. cit. supra note 70, at 151.

86. See, e.g., the action taken against Japan for its action in China, Advisory Committee on Traffic in Opium and other Dangerous Drugs, L.N. Doc. C.285. M.186. 1937.XI, p. 9.

87. Art. 14 of 1931 Convention; Art. 24 of 1925 Convention.

88. See RENBORG, op. cit. supra note 70 , at 84 .

89. See $i d$. at 93 .

90. Art. 2 of 1931 Convention.

91. Analogies between the Problem of the Traffic in Narcotic Drugs and that of the Trade in and Manufacture of Arms, L.N.Doc. Conf.D.159.1933.

92. See, e.g., Hudson and Sohn, Fifty Years of Arbitration in the Union of International Transport by Rail, 37 AMr. J. of INT'L L. 597 (1943) ; Wehle, International Administration of European Inland Waterways, 40 AMr. J. of INT'2 L. 100 (1946) ; Wilk, International Administrative Regulation-The Case of Rubber, 36 AM. PoL. Scr. REv. 323 (1942); Katz, A Case Study in International Organization, 25 HARv. Bus. Rev, 1 (1946) ; Belshaw, The Food and Agriculture Organization of the United Nations, 1 INternational Organization 291; Lehman, Some Problems in International Adninistration, 5 Pub. Adntr. Rev. 93 (1945); see also Pehle, The Bretton Woods Institutions, 55 YALE L. J. 1127 (1946); De Wolf, Telecommenication in the New World, id. at 1281.

93. Burns, International Administration, BRIT. Y. B. INT'z L. 54 (1926) ; Mander, The Immediate Tasks of International Law and Organization, 21 WASTr. L. REv, 5, 69 (1946); symposium in 31 IowA L. REv. 40-102 (1945), particularly Kunz, Expcricnce and Techniques in International Administration at 40; Pelt, Peculiar Charactcristics of an International Administration, 6 PuB. AdMIN. Rev. 108 (1946) ; Mitrany, op. cit. supra note 1. 
of administrative agencies, ${ }^{94}$ the jurisdiction of courts relating thereto, ${ }^{95}$ the embodiment of administrative decisions, ${ }^{20}$ and like matters. ${ }^{97}$ This has found its way into international law casebooks, ${ }^{38}$ but it has not been included in administrative law material.

Yet until we shall have furnished the student with the means of seeing administrative law on the local level (plumbing inspectors and health departments); in the state (public utility commissions and departments of education); nationally (SEC's and OPA's); and internationally (ITO's and UNESCO's) we shall never have given him a true perspective of administrative law. Nor, more importantly, shall we have permitted him personally to appraise the validity of the propositions that societies grow as they furnish services and that the international society can most speedily approach maturity by emphasizing its status as a service-rendering, functioning organization.

94. Rules of Permanent Court of International Justice, discussed in Hudso:, TBE Peraranent Court of International Justice 400 (1943); Corbett, II'orld Order-Am Agenda for Lawyers, 37 Axr. J. of INT'L L. 207, 218 (1943); Jessup, The Subjects of a Modern Law of Nations, 45 MicH. L. REv. 383, 390 (1946).

95. Art. 15, Rhine Protocol, Dec. 18, 1929, 5 Hudson, Intersational Legrscatro: 125; Stnata Agreensent Concerning the Danube, Art. 21, 196 Treaty Series 113 (League of Nations, 1938) ; and many other treaties.

96. United States and Gerarany, Minned Clatar Coumission; Adsm. Dec. No. II (1923), No. V (1924); see also the League of Nations Administrative Tribunal, set up in 1927, discussed in Hudson, International Trmunats 221 (1944).

97. Z. \& F. Assets Realization Corp. v. Hull, 311 U.S. 470 (1941) is not unlike the administrative law rule of F.C.C. v. Sanders Bros. Radio Station, 309 U.S. 470 (1940); Territorial Jutrisdiction of the Oder Commission in 2 Hudson, Wondd Coums Reponts 609 (1935).

98. Hudson, Cases on International Law 1160, 1161, 422n (2d ed. 1936). 